\begin{tabular}{llllll}
\hline Motrivivência & Ano XX, & No 30, P. & 07-08 & Jun./2008
\end{tabular}

\title{
A Pesquisa e a Prática Social: conhecimento, experiência, reflexão...
}

Eu estou atrás do que fica atrás do pensamento...

(Clarice lispector)

Esta edição tinha como objetivo, na sua ementa inicial, veicular produções do conhecimento cujas abordagens levassem conta a pesquisa e sua dupla vinculação à prática social: o COnhecimento para a experiência, a experiência como conhecimento; e a ação reflexiva como mediação. Esta intencionalidade visava, a priori, trazer para o debate as produções que tematizassem o caráter interventivo das reflexões filosóficas no âmbito da prática social concreta da Educação Física, Esportes e Lazer. A idéia era, a partir das pesquisas publicadas, iniciar uma reflexão acerca da dialética existente entre experiência e conhecimento, de tal modo que pudéssemos iniciar um novo ciclo teórico-metodológico, propositivo, que pudesse ser traduzido a partir da relação pesquisa e ação educativa. Fazendo agora uma apreciação dos textos publicados neste número, percebemos que, de uma certa maneira, cumprimos com os conteúdos implícitos no tema proposto Educação Física, Esportes e Lazer: Prática social, ação reflexiva e produção do conhecimento.

Este fato pode ser observado na multidimensionalidade dos temas apresentados, os quais procuram priorizar questões de natureza epistemológica, ontológica e ideológicas, traduzidas nos seguintes eixos temáticos: educação física no ensino fundamental, educação física escolar, meio ambiente, lazer, gênero (futebol feminino e homoafetividade), pesquisa (produção do conhecimento), universidade, saúde, regulamentação da profissão, racismo e outros. Como 
se pode inferir, há um esforço dos autores no sentido de conduzir seus aportes teórico-metodológicos para reflexões teórico-práticas em torno dos problemas de relevância pública oriundos do cotidiano das práticas pedagógicas (classe, raça/ etnia, gênero, geração e cultura). Neste sentido, percebe-se a necessidade, cada vez mais premente, em compreender a pesquisa como estratégia de inovação educativa a partir das abordagens práticas ${ }^{1}$.

Aliás, quanto a esse respeito, a próxima edição (no. 31), intitulada Conteúdos da Educação Física: o quê fazer? Reflexões teóricas e "propostas" didático-metodológicas, visa materializar a relação entre as pesquisas e a ação educativa concreta Educação Física, esportes e Lazer, a partir da seguinte ementa:

Na década de 90, foram apresentadas diversas propostas teóricometodológicas que visavam dar fundamentação e qualificar a prática pedagógica da EF na escola, sendo as principais: concepção crítico-superadora, críticoemancipatória, aulas abertas às experiências. No presente momento, urge refletirmos sobre a atualidade e a possível necessidade de atualização dessas obras, especialmente no que se refere aos temas/conteúdos da EF escolar
O prazo para submissão, pela plataforma de periódicos da UFSC, é até o dia 30/abril/2010. Agradecemos aos autores que, neste e nos próximos números, continuam a demonstrar confiança no projeto editorial da Motrivivência que, ao atingir sua maioridade, sempre procurou veicular, ao longo destes 21 anos, produções de pesquisadores de diferentes estágios de formação, de graduandos a pós-doutores.

Para encerrar este editorial, prestamos uma homenagem especial à La Negra, a grande cantora e militante política argentina e latinoamericana Mercedes Sosa, falecida no dia 04/10/2009 em Buenos Aires. Mercedes dedicava sua obra às canções de amor e, ao mesmo tempo, de protesto sobre as injustiças sociais cometidas contra as populações empobrecidas da América Latina. Por isto, encerramos com uma frase da música de seu disco "Corazón Libre":

\section{Adelante corazón li, sin miedo de la derrota. Durar no es estar vivo, corazón. Durar es otra cosa.}

Florianópolis, novembro/2009.

Os Editores

1 GAMBOA, S.S. Pesquisa em Educação: Métodos e Espistemologias.Chapecó:Argos, 2007. 